\title{
ECONOMIC ESTIMATION OF THE VALUE OF CACTUS PEAR PRODUCTION CONSIDERING ENVIRONMENTAL ISSUES (PÓSTER)
}

\author{
Lucia Andreu ${ }^{\mathrm{a}}$, Marina Cano $^{\mathrm{a}}$, Luis Noguera ${ }^{\mathrm{a}}$, Leontina Lipana, Ángel Carbonella, Beatriz \\ Rocamora $^{b}$, Pilar Legua ${ }^{\text {, Francisca Hernández }}{ }^{\text {, David López }}{ }^{\text {* }}$ \\ ${ }^{a}$ Centro de investigación e innovación agroalimentaria y agroambiental (CIAGRO-UMH). Escuela \\ Politécnica Superior de Orihuela (EPSO-UMH). Ctra. Beniel km 3.2. 03312 (Orihuela). Universidad \\ Miguel Hernández de Elche. Spain \\ ${ }^{b}$ Departamento de Producción y Sanidad Animal, Salud Pública Veterinaria y Ciencia y Tecnología de los \\ Alimentos. Universidad Cardenal Herrera-CEU. C. Tirant Lo Blanc, 7. Alfara del Patriarca, Valencia \\ Spain \\ *Author for correspondance: david.lopez@umh.es
}

Keywords: Opuntia, carbon soil sequestration, Spain, economic analysis

\section{Introduction}

Among the environmental implications of agriculture, climate change mitigation through soil carbon sequestration (SCS) is going to be a key question. SCS is considered an affordable and cost-effective way to mitigate the effect of agriculture to climate change (Glenk et al., 2011). Arid Mediterranean agriculture possesses a SCS potential. The case of olive tree cultivation is well documented; changing practices in favor of more sustainable agricultural procedures (Nieto et al., 2012; Rodríguez-Entrena et al., 2014) has been proved to be successful in increasing the amount of carbon in the soil (IPCC, 2003). Cactus pear is one of the few agricultural options due to the edaphic and climatic conditions in many areas. It presents advantages over other agricultural activities because of practices that attenuate, avoid and even restore damage to the productive ecosystem (Nefzaoui et al., 2014).

Bautista-Cruz et al. (2018) compared the patterns of emissions of $\mathrm{C}-\mathrm{CO}_{2}$ and total organic carbon (TOC) in a highland of central Mexico. They compared 6 management systems that included maize under several agricultural practices, cactus without and with composted manure mulching and soil in oak-pine forest. They found that TOC in cactus approached the reference line of soil under forest. Results showed that cactus crop is presently contributing effectively to the accumulation of organic carbon in the soil. Large scale plantation of spineless cactus in central- and southern-Tunisia proved that this plant species plays a key role in natural resources conservation and prevents long term degradation of ecologically weak environments (Nefzaoui et al., 2002).

An important question is how to achieve that these agricultural sustainable practices, that mitigate climate change, become part of producers' way of cultivating. From a policy perspective, ROAECS (Results Orientated Agro-Environment Climate Scheme) are a type of agro-environmental scheme based on the idea of paying landowners, not for performing management actions but for achieving specific environmental outcomes (Burton and Schwarz, 2013). As such, ROAECS encourage landowners to innovate, drawing on their experience and local knowledge to achieve improved and more cost-effective results (Colombo and Rocamora-Montiel, 2018). ROAECS can be designed to adapt not only to each production system but also to the management practices used in each farm (by not including any mandatory agricultural or management practices). A key factor to ensure reliability in ROAECS development is the existence of measurable and objective indicators (Burton and Schwarz, 2013), which must be clearly measurable, attributable to specific management actions, not in conflict with agricultural goals and consistent with ecological goals.

In this sense, sequestration of carbon (SOC) can be measured and monitored through various laboratory and field methods by using appropriate sampling procedures. Nevertheless, difficulties in monitoring and verifying the rate of SOC in a clear, cost-effective and credible manner can still exist and can, thus, arise as a potential impediment for a result-based approach in carbon sequestration (Colombo and RocamoraMontiel, 2018). In the specific case of cactus pear orchards, the indicator of SOC totally fulfils the requirements previously mentioned. This opens an opportunity to ensure sustained income and a moderate impact on the environment. In this sense, cactus pear plantations could be part of a strategy to lessen the accumulation of $\mathrm{CO}_{2}$ in the atmosphere in arid and semi-arid areas implementing ROAECS. Cactus pear plantations can function, not only as a water reserve, but as a carbon reservoir in arid and semi-arid regions offering a cost-effective contribution to climate change mitigation from the agricultural sector. Furthermore, it will reduce soil erosion and water pollution. This research explores the economic estimation 
of the possibilities of applying carbon soil sequestration schemes in cactus pear production considering environmental issues.

\section{Material and Methods}

A literature revision was undertaken to estimate $\mathrm{CO}_{2}$ accumulation in a cactus plant and the price to be paid for the carbon sequestration. Its economic value was calculated looking at its carbon sequestration and with respect to the environmental good that is generated when cultivating it. In this sense, it must be considered that research shows that agriculture production with environmental concerns would require viable subsidies for farmers. To estimate the exchange surface of each plant, 50 of them were measured in width, height and length. Then, the number of cladodes per plant was counted and 20 of each were measured in height and length to estimate their surface area. Average area of each plant and average cladode surface were calculated to estimate the exchange surface and, this way, the $\mathrm{CO}_{2}$ daily net intake for cultivated per $\mathrm{m}^{2}$ and day. The weight of a cactus plant was calculated counting the number of cladodes per plant and weighting 25 of them. Roots were not considered although they can scatter 4-8 $\mathrm{m}$ long and reach a depth of $30 \mathrm{~cm}$ (Sudzuki, 1999). Soil has not been considered.

\section{Results}

Most plants open their stomata at dawn. This is the time when they begin to take $\mathrm{CO}_{2}$ from the atmosphere, which is incorporated into various products of photosynthesis that is a process that occurs only in light. The diurnal opening of the stomata leads to an inevitable loss of water from within the leaves and the meristematic stems. In opuntias and other cactuses, the pattern of carbon dioxide $\left(\mathrm{CO}_{2}\right)$ intake and water loss occur mainly at night, when the temperature is lower and the humidity is higher, which reduces the loss of water (Nobel, 1999). The intake of $\mathrm{CO}_{2}$ and the resulting accumulation of the opuntia biomass depends on the environmental conditions. The four main factors are the soil water content, air temperature, light and various soil elements (Nobel, 1999). There are several studies that quantify this intake. Table 1 shows a summary of them. Data are considered for temperatures close to optimal, wet soil and indicated photosynthetic photon flow (PPF).

Table 1. Average temperature (T), daily total photosynthetic photon flow (PPF), soil water potential and $\mathrm{CO}_{2}$ daily net intake for cultivated CAM plants in monitored laboratory conditions

Source: Adapted from Allegra et al. (2015), Inglese et al. (1994) and Pimienta-Barrios et al. (2005).

\begin{tabular}{|c|c|c|c|c|c|c|c|c|c|}
\hline \multirow[t]{2}{*}{ CAM plants } & \multirow[t]{2}{*}{$\begin{array}{c}\text { Day/night } \\
\text { average } \\
\text { air T } \\
\left({ }^{\circ} \mathrm{C} /{ }^{\circ} \mathbf{C}\right)\end{array}$} & \multirow[t]{2}{*}{$\begin{array}{c}\text { PPF } \\
\left(\begin{array}{c}\mathbf{m o l ~ m}^{2} \mathbf{d}^{-} \\
1)\end{array}\right.\end{array}$} & \multirow[t]{2}{*}{$\begin{array}{c}\text { Soil } \\
\text { water } \\
\text { potential } \\
(\mathrm{MPa})\end{array}$} & \multirow[t]{2}{*}{$\begin{array}{c}\mathrm{CO}_{2} \\
\text { daily net } \\
\text { intake } \\
\left(\mathrm{mol} \mathrm{m}^{2}\right. \\
\left.\mathbf{d}^{-1}\right)\end{array}$} & \multicolumn{3}{|c|}{$\begin{array}{c}\mathrm{CO}_{2} \text { net intake } \\
\text { periods }\end{array}$} & \multicolumn{2}{|c|}{$\begin{array}{c}\mathrm{CO}_{2} \text { daily } \\
\text { net intake } \\
\text { contribution } \\
(\%)\end{array}$} \\
\hline & & & & & Day & Night & Total & Day & Night \\
\hline Agave salmania & $25 / 15$ & 22 & -0.2 & 481 & 5 & 12 & 17 & 3 & 97 \\
\hline Agave tequilina & $15 / 10$ & 22 & -0.1 & 298 & 6 & 12 & 18 & 30 & 70 \\
\hline O. ficus-indica & $25 / 10$ & 20 & -0.1 & 550 & 3 & 12 & 15 & 10 & 10 \\
\hline $\begin{array}{l}\text { Sten. } \\
\text { queretaroensis }\end{array}$ & $28 / 15$ & 19 & -0.2 & 317 & 6 & 12 & 18 & 14 & 14 \\
\hline
\end{tabular}

According to this, O. ficus-indica takes daily $550 \mathrm{~mol} \mathrm{CO}_{2} \mathrm{~m}^{2}$. A count has been made in 3 Spanish orchards. As an average, a 5 years old plant of $O$. ficus-indica presents 75 cladodes with an average area of $0.09 \mathrm{~m}^{2}$ each $(0.45 \mathrm{~m} \times 0.21 \mathrm{~m})$. This means an average area per plant of $7.8 \mathrm{~m}^{2}$. The average density is 714 plants per ha. So, 1 ha will contain $5,060.47 \mathrm{~m}^{2}$ of cladodes. This implies that 1 ha of $O$. ficus-indica can take 2,783,261 mol CO 2 per $\mathrm{d}$, or using other units $63.25 \mathrm{~kg} \mathrm{~d}^{-1}$. A plant of $O$. ficus-indica is fully productive when it is 5 years old and can reach 20 years of full production. As a result, 1 ha of $O$. ficusindica can take $\sim 462 \mathrm{t}$ of $\mathrm{CO}_{2}$ during its complete producing life (20 years).

In order to calculate the weight of a cactus plant, the number of cladodes were counted in 50 plants. Three cladodes per plant were weighted. A young plant (6-8 years old) presents 150 cladodes with an average weight of $2.5 \mathrm{~kg}$ each. An adult plant (20 years old) reaches, as average, 250 cladodes, leading to $\sim 625 \mathrm{~kg}$ per adult plant. According to El-Mostafa et al. (2014), García-Cayuela et al. (2019), Mena et al. (2018), the average quantity of water in a cactus pear is $80 \%$. Thus, an adult cactus pear plant has $125 \mathrm{~kg}$ of dry mass. 
The IPCC (Intergovernmental Panel on Climate Change) established that estimated amount of $\mathrm{C}$ stored by a plant is $50 \%$ of the carbon fraction contained in the dry matter, if there is no available data (IPCC, 2002). However, Gómez-Casanovas et al. (2007) indicate that the percentage of $\mathrm{C}$ in a cladode is $36.2 \%$. According to this, an adult plant has $45.25 \mathrm{~kg}$ of $\mathrm{C}\left(\sim 166 \mathrm{~kg}\right.$ of $\left.\mathrm{CO}_{2}\right)$. thus, an adult cactus pear plant fixes $8.29 \mathrm{~kg}$ of $\mathrm{CO}_{2}$ per year through its cladodes. This should be revised and checked with in-depth studies, but it allows to estimate the value of a hectare of the crop considering environmental issues.

As it has been seen, Bautista-Cruz et al. (2018) showed how cactus crop can contribute effectively to the accumulation of organic carbon in the soil. Thus, it can be stated that cactus pear cultivation can be a successful way to mitigate climate change in arid and semiarid regions.

It is obvious that the amount of $\mathrm{CO}_{2}$ that remains in the soil will depend on the agricultural practices that producers apply. It has also been analyzed that a major concern is how to implement and achieve that these agricultural sustainable practices that mitigate climate change become part of producers' way of cultivating. As presented, ROAECS are a type of agro-environmental scheme based on the idea of paying landowners for achieving specific environmental outcomes. ROAECS could be designed to adapt cactus pear production and management practices used in each plot defining measurable and objective indicators consistent with ecological goals. SOC in cactus pear farms can be an effective indicator as it totally fulfils the requirements previously mentioned. Cactus pear plantations can function, not only as a water reserve, but as a carbon reservoir in arid and semi-arid regions offering a cost-effective contribution to climate change mitigation from the agricultural sector. Furthermore, it will reduce soil erosion and water pollution.

Carbon price is an issue to be analyzed. According to Point Carbon (Reuters, 2014) carbon price estimates would remain unstable below $10 €$ during 2015 and 2016 and would drop below $5 €$ in 2020 , to rise very steeply up to around $50 €$ by 2030 . Carbon has been marketed in recent years within the EU Carbon Trading Scheme. Starting from a value close to $30 € /$ ton of $\mathrm{CO}_{2}$ in 2008 (Carbon Market Watch, 2014), since 2012 the price has persistently been under $10 € /$ ton of $\mathrm{CO}_{2}$ until March 2018 . It has been over $20 € /$ ton since December 2018. However, voluntary carbon offset prices are also affected by the compliance market, and can be higher or lower, depending on the buyer. Given the range of carbon prices and the uncertainty over which prices might apply, various scenarios should be considered. The current average value of 2020, according to the European bourse for Unit Allowances and Carbon Credits (SENDECO2, 2020) is around $25 € \mathrm{t}$ of $\mathrm{CO}_{2}$. A $20 €$ value could, therefore, represent an average estimate during the period 2020-2030, but as previously stated, there can be no guarantee as to actual carbon prices in the future (UK-Department of Energy and Climate Change, 2013). Nowadays, price is over $50 €$.

\section{Conclusions}

It has been proved that cactus pear cultivation is a successful tool to mitigate climate change in arid and semiarid regions. Obviously, farm and cultivation practices and systems are a key aspect of how cactus crop can contribute effectively to the accumulation of organic carbon in the soil. ROAECS should be designed to adapt these production and management practices defining measurable and objective indicators consistent with ecological goals.

\section{References}

Allegra, A., Sortino, G., Miciletta, G., Riotto, M., Fasciana, T. and Inglese, P. (2015). "The influence of harvest period and fruit ripeness at harvest on minimally processed cactus pears (Opuntia ficusindica L. Mill.) stored under passive atmosphere". Postharvest Biol. Technol. 104: 57-62.

Bautista-Cruz, A., Leyva-Pablo, T., de León-González, F., Zornoza, R., Martínez-Gallegos, V., FuentesPonce, M., and Rodríguez-Sánchez, L. (2018). "Cultivation of Opuntia ficus-indica under different soil management practices: A possible sustainable agricultural system to promote soil carbon sequestration and increase soil microbial biomass and activity". Land Degradation \& Development, 29(1): 38-46.

Burton, R.J.F. and Schwarz, G. (2013). "Result-oriented agri-environmental schemes in Europe and their potential for promoting behavioural change". Land Use Policy 30: 628-641.

Carbon Market Watch, (2014). What 's needed to fix the EU 's carbon market Recommendations for the Market Stability Reserve and future ETS reform proposals. Book 8. Available on line: https://carbonmarketwatch.org/publications/whats-needed-to-fix-the-eus-carbon-marketrecommendations-for-the-market-stability-reserve-and-future-ets-reform-proposals (Last acceded: 18th March 2021)

Colombo, S. and Rocamora-Montiel, B. (2018). "Result-oriented agri-environmental climate schemes as a means of promoting climate change mitigation in olive growing". Outlook Agric. 47: 141-149. 
El-Mostafa, K., El Kharrassi, Y., Badreddine, A., Andreoletti, P., Vamecq, J., El Kebbaj, M.S., Latruffe, N., Lizard, G., Nasser, B. and Cherkaoui-Malki, M., (2014). "Nopal cactus (Opuntia ficus-indica) as a source of bioactive compounds for nutrition, health and disease". Molecules 19: 14879-14901.

García-Cayuela, T., Gómez-Maqueo, A., Guajardo-Flores, D., Welti-Chanes, J. and Cano, M.P. (2019). "Characterization and quantification of individual betalain and phenolic compounds in Mexican and Spanish prickly pear (Opuntia ficus-indica L. Mill) tissues: A comparative study”. J. Food Compos. Anal. 76: 1-13.

Glenk, K. and Colombo, S. (2011). Designing policies to mitigate the agricultural contribution to cli*mate change: An assessment of soil based carbon sequestration and its ancillary effects. Clim. Change 105, 43-66.

Gomez-Casanovas, N., Blanc-Betes, E., Gonzalez-Meler, M. A., and Azcon-Bieto, J. (2007). "Changes in respiratory mitochondrial machinery and cytochrome and alternative pathway activities in response to energy demand underlie the acclimation of respiration to elevated $\mathrm{CO} 2$ in the invasive Opuntia ficus-indica". Plant physiology, 145(1): 49-61.

Inglese, P., Israel, A.A. and Nobel, P.S. (1994). "Growth and $\mathrm{CO}_{2}$ uptake for cladodes and fruit of the Crassulacean acid metabolism species Opuntia ficus-indica during fruit development”. Physiol. Plant. 91: 708-714.

IPCC: Intergovernmental Panel on Climate Chang (2002). Climate change and biodiversity. IPCC Technical paper V. IPCC-WMO-UNEP.

IPCC: Intergovernmental Panel on Climate Change (2003). Guidance for Land Use, Land-Use Change and Forestry. Intergovernmental Panel on Climate Change. Hayama (Japan).

Mena, P., Tassotti, M., Andreu, L., Nuncio-Jáuregui, N., Legua, P., Del Rio, D. and Hernández, F. (2018). "Phytochemical characterization of different prickly pear (Opuntia ficus-indica (L.) Mill.) cultivars and botanical parts: UHPLC-ESI-MSn metabolomics profiles and their chemometric analysis". Food Res. Int. 108: 301-308.

Nefzaoui, A. and Ben Salem, H. (2002). "Cacti: Efficient tool for rangeland rehabilitation, drought mitigation and to combat desertification". Acta Hortic. 581: 295-315.

Nefzaoui, A., LOuhaichi, M. and Ben Salem, H. (2014). "Cactus as a Tool to Mitigate Drought and to Combat Desertification". J. Arid L. Stud. 124, 121-124.

Nieto, O.M., Castro, J. and Fernández-Ondoño, E. (2012). "Uso sustentável de solos de olival. Influência das técnicas de maneio nas suas propriedades". Spanish J. Soil Sci. 2: 70-77.

Nobel, P. S. (1999). Biología ambiental. Agroecología, cultivo y usos del nopal. FAO, Roma (Italia).

Pimienta-Barrios, E., Zañudo-Hernandez, J., Rosas-Espinoza, V.C., Valenzuela-Tapia, A. and Nobel, P.S. (2005). "Young daughter cladodes affect $\mathrm{CO}_{2}$ uptake by mother cladodes of Opuntia ficus-indica". Ann. Bot. 95: 363-369.

Reuters, T., (2014) EU carbon price to average $€ 23 / \mathrm{t}$ between 2021 and 2030: Thomson Reuters assess the future Available at https://www.refinitiv.com/perspectives/market-insights/eu-carbon-priceaverage-e23t-2021-2030-thomson-reuters-assess-future Last acceded: 18th March 2021

Rodríguez-Entrena, M., Espinosa-Goded, M. and Barreiro-Hurlé, J. (2014). "The role of ancillary benefits on the value of agricultural soils carbon sequestration programmes: Evidence from a latent class approach to Andalusian olive groves". Ecol. Econ. 99: 63-73.

SENDECO2 (2014). Sistema Electrónico de Negociación de Derechos de Emisión de Dióxido de Carbono. Available at: http://www.sendeco2.com/es/conocenos.asp . Last accessed: 19th January 2021

Sudzuki, H. F. (1999). Anatomía y morfología. In Agroecología, cultivo y usos del nopal. Producción y protección vegetal. FAO. Roma, Italia: 29-36.

UK-Department of Energy and Climate Change (2013). Updated short-term traded carbon values for policy appraisal.

Available

at: https://www.gov.uk/government/uploads/system/uploads/attachment data/file/240095/shortterm t raded_carbon_values_used_for_UK_policy appraisal_2013_FINAL_URN.pdf. Last accessed: 18th March 2021. 